\title{
JEZUS CHRYSTUS, NASZA NADZIEJA
}

Drogi ludu Bożego Nowego Przymierza znaczone są realizmem obecności Jezusa Chrystusa, tak w odniesieniu do człowieka jak i do świata. Jest to szczególny dar Jego obecności w eschatologicznych czasach historii zbawienia. ,Ja przyszedłem po to, aby miały życie i miały je w obfitości" (J 10,10). Jezus, dobry pasterz, przyszedł po to, aby ludzie mieli życie duchowe, nadprzyrodzone w doczesności, a po śmierci to samo życie w stopniu doskonałym. Jednak rozeznanie i twórcza moc Jezusa z Nazaretu wymaga żywotności osobowych postaw człowieka wiary oraz wspólnoty Kościoła.

\section{CHRYSTUS NASZĄ WOLNOŚCIĄ}

Obserwacja życia i wizja przyszłości przepowiadania orędzia Jezusa Chrystusa pokazują niezbędność odniesienia ku nowej ewangelizacji. Trzeba tu jednak rozpoznawać także znaki czasu, poprzez które Bóg przemawia do człowieka i świata. Cała rzeczywistośc zbawienia jawi się jako doświadczenie historyczne: „chrześcijaństwo jest religią zanurzoną w historii"'. Nie mniej jednak to głoszenie światu Jezusa Chrystusa i Jego Ewangelii w celu zbawienia człowieka².

\footnotetext{
1 J a n P awe 1 II, List apostolski, ,Novo millennio ineunte”, Citta del Vaticano 2001, nr 5. Dalej jako NMI.

2 „Nakaz głoszenia Ewangelii wszystkim ludziom jest pierwszorzędnym i naturalnym posłannictwem Kościoła. (...) obowiązek ewangelizacji należy uważać za
} 
Należy zatem pójść za tym co wspiera dzieło tworzenia Królestwa Bożego, a jednocześnie przeciwstawiał się temu co jest temu przeciwne. Istnieje bowiem współcześnie wiele dzieł przeciwnych zbawczemu realizmowi Chrystusa zaofiarowanemu ludziom ${ }^{3}$. Tymczasem „Odkupiciel człowieka Jezus Chrystus jest ośrodkiem wszechświata i historii”4. Ponieważ „Chrystus zjednoczył się jakoś z każdym człowiekiem", z tej perspektywy trzeba patrzeć na teologiczną refleksję nad moralnością.

Oto imię Jezus jest ponad wszelkie imię (por. Flp 2,9), toteż w żadnym innym nie ma zbawienia (por. Dz 4,12). On jest moca i mądrością Bożą (por. 1 Kor 1,24), obrazem Boga niewidzialnego (por. 2 Kor 4,4; Kol 1,16), odblaskiem Bożej wspaniałości (por. Hbr 4,4). W Nim mieszka cała Pełnia (por. Kol 1,19; 2,9), toteż w Nim wszystko ma istnienie (por. Kol 1,17) ${ }^{6}$. Z kolei św. Jan stwierdza, że Chrystus jest Alfą i Omegą, Pierwszym i Ostatnim, Początkiem i Końcem (por. Ap 22,12), to znaczy, że przez Niego udzielana jest wszelka łaska (por. J 1,16).

łaskę i właściwe powołanie Kościoła; wyraża on najprawdziwszą jego właściwość. Kościół jest dla ewangelizacji, czyli po to, aby głosił i nauczał słowa Bożego". P a w eł VI, Adhortacja apostolska ,Evangelii nuntiandi”, Citta del Vaticano 1975, nr 14.

${ }^{3}$ „Kościół zawsze zobowiązany jest do badania znaków czasu i ich interpretowania w świetle Ewangelii, tak aby w sposób dostosowany do każdego pokolenia mógł odpowiadać na odwieczne pytania ludzi o sens życia doczesnego I przyszłego oraz ich wzajemną relację. Trzeba więc, aby świat, w którym żyjemy, a takze jego często dramatyczne oczekiwania, pragnienia I założenia były poznawane I rozumiane”. KDK 4. Por. J a n P a w eł I I, Adhortacja apostolska „Pastores dabo vobis", Citta del Vaticano 1992, nr 10.

4 J a n P a w eł II, encyklika ,Redemptor hominis", Citta del Vaticano 1979, nr 1. Dalej jako RH.

5 Tamże, nr 13.

${ }^{6}$ Por. M. He n g e 1, Il Figlio di Dio. L'origine della cristologia e la storia dekka religione giudeo-ellenistica, Brescia 1984, s. 106, 121-124; B. S e s b o u e, Pedagogie du Christ. Elements de christologie fondamentale, Paris-Montreal 1977, s. 61; R. T r e m b 1 a y, L' "innalzamento" del Figlio, fulcro della vita morale, Roma 2001, s. 30-32. 
W rzeczywistości człowieka i świata jawi się jedno z podstawowych pytań: kto jest w stanie uwolnić czy wyzwolić człowieka z sił, które prowadzą ku jego śmierci? W wymiarze ziemskim należy zauważyć podstawową konieczność: ,„pierwszą absolutnie niepodważalna prawdą naszego istnienia - poza samym faktem, że istniejemy jest nieunikniona konieczność śmierci”’. Tylko moc zbacza, którą dzięki Bożym łaskom proponuje Jezus Chrystus, nasz Pan i Zbawca. „Przez swoją śmierć Jezus rzuca światło na sens życia i śmierci każdej istoty ludzkiej. Przed śmiercią modli się do Ojca o przebaczenie dla swoich prześladowców (por. Łk 23,34), zaś łotrowi, który prosu Go, by pamiętał o nim w swoim królestwie, odpowiada: «Zaprawdę, powiadam ci: Dziś ze Mną będziesz w raju» (Łk 23,43)"».

Jego paschalne dzieło pozostaje nadzieją i szansą pełni człowieczeństwa. „On zaś umarł za nas, gdyśmy byli jeszcze grzesznikami (por. Rz 5,8). Tym samym potwierdza On, że życie osiąga swój szczyt, swój sens, swoja pełnię, kiedy zostaje złożone w darze"9. Niezbędna jest tylko pełna współpraca, w całym bogactwie godności osobowej człowieka. Potrzebne jest „owo głębokie zdumienie wobec wartości i godności człowieka"10. To jednak wymaga przekraczania siebie, a zwłaszcza własnych słabości i grzechów.

Zatem ,kontemplująca drogocenną krew Chrystusa, znak Jego ofiarowania się z miłości (por. J 13,1), człowiek wierzący uczy się dostrzegać i cenić niemalże Boską godność każdej osoby i może wołać pełen wdzięczności i radosnego zdumienia: «Jakąż wartość musi mieć w oczach Stwórcy człowiek, skoro zasłużył na tak wielkiego i tak potężnego Odkupiciela» (por. Exsultet z Wigilii Paschalnej), skoro

7 J a n P a w e 1 II, Encyklika ,Fides et ratio”, Citta del Vaticano 1998, nr 26. Dalej jako FR.

${ }^{8}$ J a n P a we 1 II, encyklika, Evangelium vitae”, Citta del Vaticano 1995, nr 50. Dalej jako EV. Por. J.A. F it z m y e r, „Oggi sarai con me in paradiso” (Lc 23,43), w: Tenże, Luca teologo. Aspetti del suo insegnamento, Brescia 1991, s. 157-178; A . $\mathrm{Fu} \mathrm{m}$ a ga $11 \mathrm{i}, \mathrm{F}$. M a n zi, Attierero tutti a me. Ermeneutica biblica ed etica cristiana, Bologna 2005, s. 65-68.

${ }^{9} \mathrm{EV}, \mathrm{nr} 51$.

${ }^{10} \mathrm{RH}, \mathrm{nr} 10$. 
«Bóg Syna swego Jednorodzonego dał», ażeby on, człowiek «nie zginął, ale miał życie wieczne» (por. J 3,16)”"11. „Królewska godność człowieka" ukazuje się w pełni w jego powołaniu do ostatecznego spełnienia w Bogu. W świetle eschatologicznego powołania „fizyczne i duchowe życie człowieka, także w swoim stadium ziemskim, zyskuje pełną wartość i znaczenie: życie Boże i wieczne jest bowiem celem, do którego zmierza i jest powołany człowiek żyjący w tym świecie"12.

\section{ORECDZIE ZMARTWYCHWSTANIA}

Wobec wielu wyzwań jakie niesie współczesność staje nadzieja chrześcijańska, która jednak wymaga zaufania Bogu. To zresztą jest jednym z wymiarów wiary. Prawdziwi uczniowie Chrystusa są szczególnie otwarci na wartości odniesione do godności człowieka. Istotnym aspektem tej godności jest „fakt Wcielenia odwiecznego Słowa", które przyjmując ludzką naturę, dokonało jej odkupienia i wywyższenia oraz zjednoczyło się z każdą ludzką istotą ${ }^{13}$.

Tu potrzeba mocnych świadków wiary, którzy stają z nadzieją wobec smutków, łez czy trudów ewangelizacji. „Oni bowiem żyjąc wewnątrz świata słysza głos Boga, który objawia im swój plan i oznajmia szczególne powołanie do tego, by szukali Królestwa Bożego zajmując się sprawami Bożymi i kierując nimi po myśli Bożej"14. W mocach Jezusa, i to zmartwychwstałego, wszystko to staje się realnym darem drogi ewangelizacyjnej obecności. Należy zwiastować Chrystusa i wartości chrześcijańskiego życia, także na

${ }^{11}$ EV, nr 25. Por. B e n e dy k t XVI, Encyklika „Deus caritas est”. Citta del Vaticano 2005, nr 13. Dalej jako DC; RH, nr 10. Por. D. M o 11 a t, hasło „Chwała”, w: Słownik Teologii Bibilnej, red. X. Leon-Dufour, Poznań 1994, s. 138; R. T r e m b 1 a y, „Ma io vi dico...”. L'agire eccelente, specifico della morale cristiana, Bologna 2005, s. 34-39.

$12 \mathrm{EV}, \mathrm{nr} 30$.

13 Tamże, nr 2; RH, nr 13.

14 RH, nr 5; Por. J a n P a w e 1 II, Adhortacja apostolska „Christifideles laici”, Citta del Vaticano 1988, nr 16. 
„,nowożytnych areopagach”15. „Tych «areopagów» jest dziś wiele i sa bardzo różne. Sa to wielkie tereny współczesnej cywilizacji i kultury, polityki i ekonomii. Im bardziej Zachód odrywa się od swych chrześcijańskich korzeni, tym bardziej staje się terenem misyjnym, w znaczeniu wielorakich «areopagów»"

Zmartwychwstały „Jezus jest prawdziwą nowością przerastającą oczekiwania ludzi, a pozostanie nią na zawsze, przez wszystkie kolejne epoki dziejów. Wcielenie Syna Bożego oraz zbawienie, jakiego dokonał przez swoją śmierć i zmartwychwstanie, są zatem właściwym kryterium oceny rzeczywistości doczesnej i wszelkich zamysłów, które mają zapewnić człowiekowi życie coraz bardziej ludzkie"17. Chodzi o głoszenie samego Jezusa Chrystusa ${ }^{18}$ wraz z całym bogactwem owoców dokonanego przez Niego dzieła zbawienia. Życie związane z osobą Jezusa Chrystusa zmartwychwstałego nie neguje tego wszystkiego, co ludzkie doświadczenie i rozum mówią o wartości życia w porządku stworzenia, ale „przejmuje to, wywyższa i dopełnia”"19.

Trzeba współcześnie być czytelnym oraz żywym nosicielem nadziei, ale tej która oparta jest na dziełach Boga, na wierności Jego słowom, która ma ostateczny fundament w pewności zmartwychwstania Chrystusa. „Człowiek, który chce zrozumieć siebie do końca - nie wedle jakichś tylko doraźnych, częściowych, czasem powierzchownych, a nawet pozornych kryteriów i miar swojej własnej istoty - musi ze swoim niepokojem, niepewnością, a także słabością i grzesznością, ze swoim życiem i śmiercią, przybliżyć się do Chrystusa. Musi niejako w Niego wejść z sobą samym, musi sobie przyswoić, zasymilować całą rzeczywistość Wcielenia i Odkupienia, aby siebie odnaleźć"20.

15 Por. J a n P aw e 1 II, encyklika „,Redemptoris missio”, Citta del Vaticano 1990, nr 37. Dalej jako RM.

16 J a n P aw e 1 II, List apostolski ,Tertio millennio adveniente”, Citta del Vaticano 1994, nr 57. Dalej jako TMA.

17 J a n P a w e 1 II, Bulla ogłaszająca Wielki Jubileusz Roku 2000 „Incarnationis mysterium”, „L'Osservatore Romano” 20:1999 nr 1, nr 1.

18 Por. EV, nr 29

19 EV, nr 30; Por. EV, nr 29.

20 RH, nr 10. 
Ten dar zmartwychwstałego Pana pozostanie na zawsze skutecznym oraz owocnym. W perspektywie teologicznej ,śmierć jest czymś całkowicie innym niż doświadczenie beznadziejności: jest bramą istnienia otwartą na wieczność, a dla przeżywających ją w Chrystusie uczestnictwem w Jego tajemnicy śmierci i zmartwychwstania"21. Dlatego też „śmierć może być źródłem życia i miłości”22.

Chrystusowe pełne zwycięstwo nad grzechem i śmiercią jest orędziem i źródłem całej ewangelizacji w czasie ziemskiego pielgrzymowania. Jest ono gwarantem rozwoju oraz pełni człowieczeństwa ${ }^{23}$. Dlatego „na tajemnicę grzechu składa się ta podwójna rana, którą grzesznik otwiera w sobie w w stosunkach z bliźnimi. Stąd można mówić o grzechu osobistym i społecznym: pod pewnym względem każdy grzech jest ososbisty; pod pewnym zaś - każdy grzech jest społeczny, na ile, i ponieważ, pociąga za sobą również sktuki społeczne"24.

\section{KOCHAJĄCA NADZIEJA}

Niezbędnym jest bycie człowiekiem wiary, który ufnie odnosi się do Bożych obietnic, a zatem ma spokój i pewność spojrzenia ku przyszłości, choć nie jest mu obojętna i realna teraźniejszość.

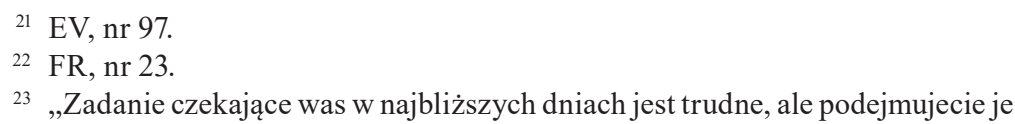
pod znakiem nadziei, której źródłem jest zmartwychwstały Chrystus. Wasza misja polega na głoszeniu nadziei, o której mówi apostoł Piotr (por. 1 P 3,15): nadziei opartej na Bożych obietnicach i na wierności Jego słowu, nadziei, której niewzruszonym pewnikiem jest zmartwychwstanie Chrystusa, Jego ostateczne zwycięstwo nad grzechem i śmiercią - pierwsze orędzie i korzeń wszelkiej ewangelizacji, podstawa postępu człowieka, początek każdej autentycznej kultury chrześcijańskiej, która może być tylko kulturą zmartwychwstania i życia, ożywianą tchnieniem Ducha Pięćdziesiątnicy". J a n P aw eł II, Nowa ewangelizacja, postęp człowieka, kultura chrześcijańska. Przemówienie wygłoszone na otwarcie obrad IV Konferencji Ogólnej Episkopatu Ameryki Łacińskiej, „L’Osservatore Romano” 12:1992, nr 12, nr 25.

24 J a n P aweł II, Adhortacja apostolska,,Reconciliatio et paenitentia”, Citta del Vaticano 1984, nr 15. Dalej jako RP. 
Przeznaczeniem człowieka i całych społeczeństw jest życie, bytownaie ku życiu. „Człowiek wierzący wie, że jego życie jest w ręku Boga: «Ty, Panie, mój los zabezpieczasz» (por. Ps 16,5) i godzi się przyjąć od Niego także śmierć: «Taki jest wyrok wydany przez Pana na wszelkie ciało: i po co odrzucać to, co się podoba Najwyższemu?» (Syr 41,4). Człowiek nie jest panem śmierci, tak jak nie jest panem życia; w życiu i w śmierci musi zawierzyć się całkowicie «woli Najwyższego», zamysłowi Jego miłości"25.

Ostatecznie, tylko Bóg - Jezusie Chrystusie - przepełniony miłością prowadzi historię, a miłość prawdziwa jest zawsze pewna i godna zaufania. „Sprawiedliwość śmierci zostaje wymierzona za cenę śmierci Tego, który był bez grzechu, i który jeden mógł - przez swoją smierć - zadać śmierć śmierci (por. 1 Kor 15,54-55). W ten sposób krzyż Chrystusa, w którym Syn, współistotny Ojcu, oddaje pełną sprawiedliwość samemu Bogu, jest równocześnie radykalnym objawieniem miłosierdzia, czyli miłości wychodzącej na spotkanie tego, co stanowi sam korzeń zła w dziejach człowieka: na spotkanie grzechu i śmierci"26.

Kto jest kochanym ma nadzieję ku przyszłości, ponieważ wie, że miłość nie ma ograniczeń czasu ani końca jej trwania (por. 1 Kor 13,13). Jest ona jednym $\mathrm{z}$ darów poza i ponadczasowych (por. Kol 1,4-5; 1 Tes 1,3; 5,8). Zatem miłość większa jest nawet od wiary i nadziei, tj. od tych dwu cnót, których przedmiotem jest również Bóg i które są tak ważne w ziemskim pielgrzymowaniu. Przyjdzie czas, gdy człowiek przestanie już żyć nadzieją, bo osiągnie to, czego się całe życie spodziewał. Zbyteczna okaże się wiara, bo będzie Boga oglądał bezpośrednio (por. 1 Kor 13,12). Świadectwa, pośredniki, okażą się zbyteczne. Zostanie tylko miłośćc ${ }^{7}$.

$25 \mathrm{EV}, \mathrm{nr} 46$.

26 J a n Paw e 1 II, Encylkika, Dives in misericordia”, nr 8. Dalej jako DM.

27 Por. E.X. D u r rwe 11, Cristo nostra Pasqua, San Paolo 2003, s. 182-183; C. R e y n i e r, M. Tri m a i 11 e, A. V a n h o y e, Lettere di Paolo, t. 2, Cinisello Balsamo 2000, s. 187-189; F. R u i z, Le vie dello Spirito. Sintesi di teologia spirituale, Bologna 1999, s. 57-60. 
Bóg m.in. w różnych aktach historycznych pokazał ludziom, iż można w Nim mieć pełne zaufanie. Można w Nim widzieć fundament oraz gwaranta swych dróg życia. Szczytem tego dzieła jest dar Jezusa Chrystusa: „W tym objawiła się miłość Boga ku nam, że zesłał Syna swego Jednorodzonego na świat, abyśmy życie mieli dzięki Niemu" (1 J 4,9-10). Bóg objawia swą miłość w sposób szczególny w posłaniu Jednorodzonego Syna, który umarł na krzyżu, aby przebłagać Boga za nasze grzechy. Oddanie własnego Syna za nas to największe dzieło miłości Boga. Nie myśmy dali początek miłości, lecz Bóg, który w Chrystusie dał samego siebie w darze. Najpełniej objawiła się światu miłość wcielona w osobie Jezusa Chrystusa: jest ona samą dobrocią (por. Tt 3,4) i miłosierdziem. W ten sposób Bóg, którego w Starym Testamencie nikt nigdy nie widział (por. J 1,18), staje się dostępny dla każdego, kto chce czerpać z tego niewyczerpanego źródła miłości. Jednorodzony Syn przynosi nam życie z pełni Ojca (por. J 5,26) i udziela go. Jezus Chrystus przybył do nich jako ofiara przebłagalna (por. J 2,2; 3,16) i właśnie przez to przepaść między człowiekiem a Bogiem, jaką stworzył grzech, został zniwelowany ${ }^{28}$.

Owocne wejście Jezusa w historię pozostanie już na zawsze znamieniem nowości czasów mesjańskich (por. Łk 4,16-30). „Tak bowiem Bóg umiłował świat, że Syna swego Jednorodzonego dał, aby każdy, kto w Niego wierzy, nie zginął, ale miał życie wieczne" (J 3,16). Chrześcijanin wie, że nie jest sam, że Chrystus jest zawsze razem z nim jako poręczyciel jego nadziei ${ }^{29}$. „Nowe życie” jest dane na tym świecie tylko w formie zaliczki jako, ,zadatek Ducha” (2 Kor 1,22), a pełni będzie dane w stadium eschatologicznym ${ }^{30}$.

Trudno odtąd spodziewać się większego dar zaofiarowanego przez Stwórcę człowiekowi, a w nim i światu (por. Łk 11,29-32). „Jesus jest

28 Por. R. Tre m b la y, L"' innalzamento”, dz. cyt., s. 42-44; R. E. B r o w n, Giovanni. Commento al Vangelo spirituale, Assisi 1999, s. 77-84.

29 Por. RP, nr 20-22.

30 Por. Kongregacja Nauki Wiary, Deklaracja „,Dominus Iesus”, Citta del Vaticano 2000, nr 22-23; G. Fro s i n i, Lo Spirito che da la vita. Una sintesi di pneumatologia, Bologna 1997, s. 178-182; L. Tremblay. L'“innalzamento”, dz. cyt., s. 51-54. 
«nowym stworzeniem» (por. Ef 4,24; Kol 3,10), (...) wzywa odkupioną ludzkość do udziału w Jego Boskim życiu. W tajemnicy Wcielenia położone zostały podwaliny antropologii, która zdolna jest przekroczyć własne ograniczenia i sprzeczność, zmierzając ku samemu Bogu, a nawet więcej - ku «przebóstwieniu» poprzez wszczepienie w Chrystusa człowieka odkupionego, dopuszczonego do udziału w życiu trynitarnym"31. W tajemnicy Wcielenia Słowa prawda i mądrość Boża zostały wypowiedziane raz na zawsze oraz weszły w czas i historię: „Historia jest zatem dla Ludu Bożego drogą, którą ma on przejść w całości, aby dzięki nieustannemu działaniu Ducha Świętego ukazała się w pełni treść objawionej prawdy (por. J 16,13)"32.

\section{NOWOŚĆ ŻYCIA W CHRYSTUSIE}

Wraz z wejściem Chrystusa w świat Ojciec wyraził wobec ludzkości ostateczne tak (por. 2 Kor 1,20), które zapewnia nieodwołalną propozycję zbawienia wobec wszystkich. I jest to „decydujące wydarzenie we wszechświecie, wydarzenie, które odnawia stworzenie, przywracając wszechświatowi i człowiekowi Jego początkową chwałę Bożą. Człowiek zaś realizuje się w sposób prawdziwy, kiedy uczestniczy w życiu Boga"33. Dzieło Chrystusa ukazuje się jako zwycięstwo nad złem, pozwalające człowiekowi przejść ze stanu poniżenia i grzechu do „,nowego życia” przybranego dziecka Bożego, do odnowienia w swojej istotnej głębi zasadniczego powołania człowieka ${ }^{34}$.

${ }^{31}$ NMI, nr 23. Por. H . U. v o n B a 1 t h a s a r, Spiritus Creator. Saggi teologici, t. 3, Brescia 1972, s. 143-146; M. R h o $\mathrm{n}$ h e i m e r, La prospettiva della morale. Fondamenti dell'etica filosofica, Roma 1994, s. 43-50.

32 FR, nr 11.

33 Jezus Chrystus, jedyny Zbawiciel świata, wczoraj, dziś i na wieki. Oficjalny dokument Papieskiego Komitetu Obchodów Wielkiego Jubileuszu Roku 2000, Katowice 1997, s. 40; Por. H. U. v o n B a 1 t h a s a r, Teologia misterium paschalnego, Kraków 2001, s. 167-170; L. Tremblay. L" "innalzamento”, dz. cyt., s. $42-$ -47; H. U. von B a 1 th a s a r, Teodrammatica. 5: L'ultimo atto, Milano 1986, s. 238-243.

$34 \mathrm{RH}, \mathrm{nr} 13$. 
Chrystus uosabiał prawdomówność nie tylko ze względu na osobista wiernośc prawdzie, lecz także dlatego, że w Nim okazały się prawdą wszystkie obietnice Boga dane ongis Izraelowi, w przez ten narod całej ludzkości. Tej prawdomówności i wierności Bogu Kościół składa hołd swoim własnym „tak”, wypowiadany uroczyśnie w „Amen”, które kończą się wszystkie modlitwy zanoszone do Boga przez Jezusa Chrystusa (por. Rz 1,8; 1 P 4,11; Jud 25).

Narodzenie Jezusa jest zapoczątkowaniem Ewangelii, dobrej nowiny, a więc szansy nowości życia. Wszystko to, co On powiedział i uczynił, było świadectwem, które zapoczątkowywało oczekiwany rok łaski od Pana (por. Łk 4,19). To był początek spełniania się licznych prorockich zapowiedzi, a jednocześnie nadziei Starego Przymierza. Mając na względzie całe dzieje zbawienia, „nadzieja chrześcijańska podejmuje i wypełnia nadzieję narodu wybranego, mająca swoje źródło i wzór w nadziei Abrahama, który (...), «wbrew nadziei uwierzył nadziei, że stanie się ojcem wielu narodów» (Rz 4,18)"35.

To posłannictwo Jezusa z Nazaretu, w Duchu Pańskim, z namaszczeniem w celu posłannictwa mesjańskiego, aby nieść dobrą nowinę ubogim, głosić wolność więźniom, a niewidowym możność widzenia (por. Iz 58,6; 61,1-2). Dzięki tej wierze w niepowtarzalne wydarzenie wydarzenie historiozbawcze (Verbum Caro), że Bóg umiłował człowieka przez Syna swego Jezusa Chrystusa, Jego rozumienie moralności, zasadniczo dostepne człowiekowi, staje się bardziej pełne i dogłębne. „Dzięki pomocy łaski Bożej i przy współpracy ludzkiej wolności zawsze pozostaje dla człowieka otwarta duchowa przestrzeń nadziei" "36. Te odwołania daja nową wyobraźnie nadziei zbawczej w Jezusie Chrystusie.

Jezus Chrystus, jako jedyny, sumuje sam w sobie wszystkie dzieła mesjańskie, gdy ogłasza zbawienie, zwłaszcza wobec wszystkich grzeszników. „Idźcie i oznajmijcie Janowi to, co słyszycie i na co patrzycie; niewidomi wzrok odzyskują, chromi chodzą, trędowaci doznają oczyszczenia, głusi słyszą, umarli zmartwychwstają, ubogim

35 KKK 1819.

36 Jan Paw e 1 II, Encyklika „,Veritatis splendor”, nr 103. Dalej jako VS. 
głosi się Ewangelię” (Mt 11,4-5). Zatem Kościół uczy o grzechu w perspektywie zbawczego działania Boga, „w której grzech zostaje skonfrontowany z prawdą Bożej miłości: sprawiedliwej, wielkodusznej i wiernej, ujawniającej się nade wszytsko w przebaczeniu i odkupieniu" 37 .

Z jednej strony grzech odsłania tajemnicę nieprawości (misterium iniquitatis), z drugiej - trzeba to widzieć w świetle tajemnicy zbawienia (mystrerium pietatis), która odsłania zwycięstwo nad grzechem ${ }^{38}$. Prawad, że miłość Boża jest potężniejsza niż grzech, najpełniej objawia się w krzyżu Chrystusa i potwierdza w Jego zmartwychwstaniu $^{39}$. Dlatego też, „Żaden grzech człowieka nie może uchylić Bożego Miłosierdzia, nie może go powstrzymać przed ujawnieniem całej swej zwycięskiej mocy, jeśli tylko jej wezwiemy"40.

To jest już realizm znamion Nowego Przymierza, znaczony dziełami łask w Chrystusie. Odpowiedź Jezusa, pozornie wymijająca, w swej treści jest stwierdzeniem, że Jezus urzeczywistnia proroctwa mesjańskie Starego Testamentu, te zwłaszcza, które mówią o pokornym i cierpiącym Słudze Jahwe. Stąd aluzja do kilku równocześnie miejsc Księgi Izajasza: niewidomi i głusi (por. Iz 35,5); umarli (por. Iz 26,19); ubodzy, nieszczęśliwi, wyczekujący pociechy (por. Iz 61,1). W ten sposób zostały cokolwiek skorygowane mesjańskie przekonania Jana Chrzciciela. Tak więc same czyny Jezusa są odpowiedzią na pytania uczniów Jana.

Spotkanie człowieka z Chrystusem owocuje nie tylko uwielbieniem Boga, lecz także głębokim zdumieniem człowieka nad sobą samym. Dopiero Chrystus objawia w pełni człowieka samemu człowiekowi ${ }^{41}$. „Kościół, idąc za Chrystusem, stara się wnosić w dzieje człowieka organiczne i dogłębne zespolenie obojga"42. Dlatego

\footnotetext{
37 RP, nr 13.

38 Por. RP, nr 19.

39 Por. DM, nr 8.

$40 \mathrm{VS}, \mathrm{nr} 118$.

${ }^{41} \mathrm{RH}, \mathrm{nr} 10$.

42 DM, nr 1.
} 
człowiek pozostaje dla Kościoła na zawsze pierwszą i podstawową droga wyznaczoną przez samego Chrystusa ${ }^{43}$.

\section{PASCHALNE KRÓLESTWO}

Tematem centralnym nauczania Jezusa jest nadejście Królestwa Bożego, które zostaje darmo zaofiarowane ku zbawieniu wobec wszystkich (por. Mk 1,15). Treść ewangelii, czyli dobrej nowiny, stanowi bliskość Królestwa Bożego oraz wezwanie do nawrócenia i wiary w tę dobrą nowinę. Wewnętrzne nawrócenie się, czyli całkowita zmiana duchowego nastawienia odwracająca człowieka od zła, a kierująca do Boga, wprowadza do tego Królestwa ${ }^{44}$. Przyjęcie orędzia Ewangelii zakłada zgodę na nowy styl postepowania, ukazany w życiu i słowach Chrystusa. Wręcz nawrócenie jawi się jako konsekwencja przyjęcia wiary. Chodzi o, ,pełne i szczere przylgnięcie do Chrystusa i do Jego Ewangelii poprzez wiarę"45.

Królestwo Boże szczególnie ma jednak odniesienie do biednych, maluczkich i grzeszników. Chrystus jest przecież „w szczególny sposób obecny w ubogich, dlatego wobec nich Kościół winien stosować «opcję preferencyjną». Poprzez tę opcję dajemy świadectwo o kształcie miłości Boga, o Jego opatrzności i miłosierdziu i w pewien sposób nadal rozsiewamy w dziejach ziarna Królestwa Bożego, które sam Jezus pozostawił w czasie swego ziemskiego życia, wychodzać naprzeciw tym, którzy zwracali się do Niego z wszelkimi potrzebami

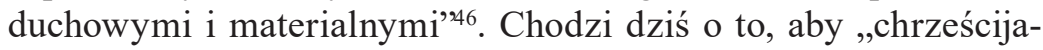
nin uczył się wyrażać swa wiarę w Chrystusa przez odczytywanie ukrytego wezwania, jakie On kieruje do niego ze świata ubóstwa"47.

Bliskość Królestwa Bożego nie oznacza, iż równocześnie kończy się istnienie świata w jego dotychczasowej, materialnej postaci.

\footnotetext{
43 Por. RH, nr 14, 21.

44 Por. RP, nr 26.

$45 \mathrm{RM}, \mathrm{nr} 46$.

46 NMI, nr 49.

47 Tamże, nr 50.
} 
Znaczy to, że władzę nad światem istotnie obejmuje Bóg, a to, że niewidomi widzą, chromi chodzą i głusi słyszą, stanowi najbardziej przekonujący dowód nie tylko bliskości, lecz nawet obecności głoszonego przez Chrystusa Królestwa (por. Mt 11, 4-6; Łk 7,21-23). W Nim spełniają się proroctwa mesjańskie (por. Iz 29,18-19; 35,5-6). W perspektywie historiozbawczej - odwołując się do uniwersalizmu zbawienia - „każdy bez wyjątku” jest odkupiony, gdyż z „,każdym bez wyjątku" Chrystus jest zjednoczony ${ }^{48}$.

Mesjańskim dziełom towarzyszyły zbawcze zapowiedzi znaczone cudami, ale uwarunkowanymi wyzwoleniem ludzi od największej niewoli, jaką jest grzechu, która przeszkadza w spełnianiu powołaniu do synostwa Bożego. To pytanie o naruszenie osobowej więzi z Bogiem, niewierność, a nawet wzgardzenie Bożą miłością. To także szansa uwolnienia od wszelkiego zniewolenia ${ }^{49}$. Ta nadzieja opiera się nie tylko na tajemnicy Bożego miłosierdzia, lecz także na przekonaniu, że ,ciemności błędu i grzechu nigdy jednak nie zdołają do końca zgasić w człowieku światła Boga Stwórcy"50. Człowiek może bowiem - mocą własnego wysiłku, ale nade wszystko wsparty darami Bożymi - zwyciężyć grzech w sobie ${ }^{51}$.

Centralnym znamieniem i fundamentem wiary oraz ufnej nadziei chrześcijańskiej jest misterium paschalne, nowotestamentalne przejście Mistrza z Nazaretu. Dzięki tej wierze w niepowtarzalne wydarzenie historiozbawcze (Verbum Caro), że Bóg umiłował człowieka przez Syna swego Jezusa Chrystusa, Jego rozumienie moralności, zasadniczo dostępne człowiekowi, staje się bardziej pełne

48 Por. RH, nr 14.

49 „Wyzwalając niektórych ludzi od ziemskich cierpień: głodu, niesprawiedliwości, choroby I śmierci, Jezus wypełnił znaki mesjańskie. Nie przyszedł On jednak po to, by usunąć wszelkie cierpienia na ziemi, ale by wyzwolić ludzi od największej niewoli - niewoli grzechu, która przeszkadza ich powołaniu do synostwa Bożego I powoduje wszystkie inne ludzkie zniewolenia". KKK 549.

50 VS, nr 1.

${ }^{51}$ Por. J a n P a w 1 II, encyklika,,Sollicitudo rei socialis”, nr 47. Dalej jako SRS. 
i dogłębne ${ }^{52}$. „Jeżeli natomiast brakuje Bożego fundamentu i nadziei życia wiecznego, godnośc człowieka, jak to się często dzisiaj stwierdza, doznaje bardzo poważnego uszczerbku, a tajemncie życia i śmierci, winy i cierpienia pozostają bez rozwiązania, tak że ludzie nierzadko popadają w zwątpienie" 53 .

Paschalne misterium to szczególny znak owocnej miłości i życia Jezusa Chrystusa, ale i tych samych wartości zaproponowanych innym. Dzieki paschalnej nadziei ,„pragniemy jako naszego szczęścia Królestwa niebieskiego i życia wiecznego, pokładając ufność w obiuetnicach Chrystusa i opierając się nie na naszych siłach, ale na pomocy łaski Ducha Świętego. «Trzymajmy się niewzruszenie nadziei, którą wyznajemy, bo godny jest zaudania Ten, który dał obietnicę» (Hbr 10,23). On «wylał na nas obficie (Ducha Świętego) przez Jezusa Chrystusa, Zbawiciela naszego, abyśmy, usprawiedliwieni Jego łaską, stali się w nadziei dziedzicami życia wiecznego» (Tt 3,6-7)"’54. W Chrystusie paschalnym ,dla chrześcijanina sytuacja nigdy nie jest beznadziejana. Chrześcijanin jest czlowiekiem nadziei"55.

W śmierci i zmartwychwstaniu Chrystusa Bóg Ojciec ukazuje ludziom, że miłość zwycięża wszystko, aż do zwycięstwa grzechu i śmierci. „Dla przeżywających ją w Chrystusie uczestnictwem w Jego tajemnicy śmierci i zmartwychwstania" ${ }^{56}$. Przecież wskazuje na Chrystusa jako na Odkupiciela świata, właśnie za sprawą swojej krzyżowej śmierci i zmartwychwstania. Wyznajemy tę wiarę słowami Symbolu Nicejsko-Konstantynpolitańskiego, który mówi: „Ukrzyżowany również za nas, pod Poncjuszem Piłatem, został umęczony i pogrzebany. I zmartwychwstał dnia trzeciego" ${ }^{57}$. Kto wierzy w Pana ostatecznie nie może ulec przemianie ku złu, ale ma nadzieję życia.

52 Por. FR, nr 15

53 KDK 21.

${ }^{54}$ KKK 1817. Por. RH, nr 10; VS, nr 38-39.

55 J a n P aw e 1 II, Dla chrześcijan sytuacja nigdy nie jest beznadziejna. Spotkanie w młodzieża. Wsterplatte, „L'Osservatore Romano” 8:1987 nr 5bis, nr 7.

$56 \mathrm{EV}, \mathrm{nr} 97$.

${ }^{57}$ Mszal rzymski dla diecezji polskich. Wydanie drugie, poszerzone. Poznań 2010, s. 14*. 
Właśnie „dzięki pomocy łaski Bożej i przy współpracy ludzkiej wolności zawsze pozostaje dla człowieka otwarta duchowa przestrzeń nadziei”"58. To daje nową wyobraźnią nadziei paschalnego Królestwa Jezusa.

\section{WIARA KU ZMARTWYCHWSTANIU}

Bóg w Starym Testamencie, który objawiał się jako Stwórca i Dawca życia (por. Rdz 2,7; Wj 37,14), właśnie w Chrystusie ukazuje się ludziom jako Bóg Zmartwychwstały ${ }^{59}$. Bóg bowiem nie tylko obdarowuje człowieka życiem, ale jednocześnie obdarowuje go swoją miłością i naznacza charakter przekraczający ramy przyrodzone. Dar życia ludzkiego w tych wymiarach jest istotnie związany z osobą Jezusa Chrystusa. W Nim zostaje objawiona cała prawda o życiu; w Nim życie ludzkie zostaje na nowo stworzone (odnowione) i przebóstwione (por. 2 Kor 5,17; Ga 6,15); w Nim zostaje też ofiarowana perpsketywa życia wiecznego, przekraczającego ramy doczesności i urzeczywistniającego się w zjednoczeniu z Ojcem ${ }^{60}$. Taka prawda o życiu stanowi treść „Evangelium vitae”61 a jej głoszenie oznacza w praktyce głoszenie samego Jezusa Chrystusa zmartwychwstałego ${ }^{62}$.

W darze ludzkiego i osobowego życia Bóg użyczył człowiekowi coś z siebie samego (por. Rdz 1,26), wyróżniając go tym samym od innych stworzeń. Wybrzmiewa tutaj materialnoduchowa matura

58 VS, nr 103.

59 Por. V. G a s p a r, Cristologia pneumatologica in alcuni autori postconciliari (1965-1995). Status quaestionis e prospettive, Roma 2000, s. 15-19; J. G a 1 o t, L'Esprit Saint, personne de communion, Saint-Maur 1997, s. 82-84; G . v o n R a d, Genesi. La storia delle origini, Brescia 1993, s. 93-118; C. W e s t e r m a n n, Genesi, Casale Monferrato 1989, s. 27-41.

60 Por. KKK 1265; H.U. von Balthasar, Spiritus Creator..., dz. cyt., s. 143-147;

R. Penna, L'apostolo Paolo. Studi di esegesi e teologia, Cinisello Balsamo 1991, s. 658-670; S. L e g a s s e, L'Epitre de Paul aux Galates, Paris 2000, s. 478-482.

61 Por. EV, nr 29-30.

62 Por. tamże, nr 29. 
człowieka ${ }^{63}$. „Bóg, stwarzając człowieka na swój obraz, pragnął dać mu udział wswoim panownaiu i chwale"64. Dlatego Dobra Nowina to „owo głębokie zdumienie wobec wartości i godności człowieka”65. Istotnym, wręcz fundamentalnym elementem jest tutaj „fakt Wcielenia odwiecznego Słowa", które przyjęło ludzką naturę, dokonało jej odkupienia i wywyższenia oraz zjednoczyło się z każdą ludzką istotą $^{66}$.

Ojciec objawił jednak przyszłość dopiero w mocach zmartwychwstałego Chrystusa. W Nim człowiek wiary uczestniczy w Jego życiu, które zwycięża śmierć, ale jeśli przyjmuje on jednocześnie Go jako Zbawiciela, a co znajdzie swe spełnienie w ostatecznym zmartwychwstaniu: „Kto wierzy w Syna, ma życie wieczne” (J 3,36). Życie wieczne, zainaugurowane w Jezusie Chrystusie w teraźniejszości, zdąża nieodwołalnie w kierunku dopełnienia w wieczności. Jedyną przeszkodę na tej drodze może stanowić przerwanie tego stanu „trwania” w Chrystusie: grzech, czyli powrót do sfery nieprawości. A w innym miejscu: ,Ja przyszedłem po to, aby miały życie i miały je w obfitości” (J 10,10). Jesus, Dobr Pasterz, przyszedł po to, aby ludzie mieli zycie duchowe, nadprzyrodozne w doczesności, a po śmierci to samo zycie w stopniu doskonalszym (por. J 10,1-18) ${ }^{67}$.

To jest centralnym wyrazem wiary i nadziei chrześcijańskiej. Wiara w Chrystusa związana jest ze stwierdzeniem: „,Ja jestem zmartwychwstaniem i życiem. Kto we Mnie wierzy, choćby i umarł, żyć

${ }^{63}$ Por. E. M. C u r t i s, Image of God, w: The Anchor Bible Dictionary, t. 3, New York 1992, s. 389-391; L. F. L a d a r i a, Antropologia teologica. L'uomo: paradosso e mistero, Bologna 1997, s. 67-94.

${ }^{64} \mathrm{~J}$ a n P awe 1 II, Każdy człowiek nosi w sobie obraz i podobieństwo Boże. Przemówienie do uczestników Międzynarodowej Konferencji poświęcnej umysłowo chorym, „L'Osservatore Romano” 18:1997 nr 2 nr 4.

$65 \mathrm{RH}, \mathrm{nr} 10$.

66 Por. EV, nr 2; RH, nr 13.

${ }^{67}$ Por. R. Tremblay, „Ma io vi dico...”, dz. cyt., s. 34-39; R. S c h n a c k e n b u r g, Il Vangelo di Giovanni, t. 2, Brescia 1981, s. 94-96; R. Tr e m b 1 a y, Radicati e fondati nel Figlio. Contributi per una morale di tipo fiiale, Roma 1997, s. 37-40. 
będzie. Każdy, kto żyje i wierzy we Mnie, nie umrze na wieki" $(\mathrm{J} 11,25-26)^{68}$. Chrześcijanin należy w życiu i śmierci do Jezusa Chrystusa (por. Rz 14,7-8), w którym jedynie jest prawdziwe życie (por. J 1,4); w tym znaczneniu życie i śmierć jako zjawiska naturalne nabierają sensu relatywnego, gdy tymczasem życie i śmierć wieczna maja charakter definitywny, absolutny i nieodwracalny ${ }^{69}$. Dlatego św. Jan wskazuje na konsekwencje etyczne tego decydującego kroku ku Chrystusowi: „My wiemy, że przeszliśmy ze śmierci do życia, bo miłujemy braci; kto zas nie miłuje, trwa w śmierci" (1 J 3,14). Krok ten wymaga pełnej wiary w Jezusa (por. J 11,26), jako „Mesjasza” (por. J 1,41), Syna Bożego i „Tego, który miał przyjść na świat” jako jego Zbawca (por. J 6,14; Mt 11,3; Łk 7,19).

Podstawowym orędziem Ewangelii jest zwiastowanie radosnego faktu, że Jezus Chrystus, Syn Boży, stał się człowiekiem, umarł i zmartwychwstał dla wszystkich ludzi, jako dar łaski i znak miłosierdzia Bożego. Zatem „objawienie miłości i miłosierdzia ma w dziejach człowieka jedna postać i jedno imię. Nazywa się: Jezus Chrystus"70, albowiem ,przez Chrystusa i w Chrystusie Bóg wychodzi na poszukiwanie człowieka i czyni to z potrzeby ojcowskiego serca"71. W Nim całość dzieła ożywiała posłuszna miłość ku Ojcu a w Nim i ku ludziom (por. Mt 26,36-46). Stąd misterium paschalne stanowi szczytowy punkt objawienia miłosierdzia, a więc także owego wychylenia ku zmartwychwstaniu ${ }^{72}$. „Żaden grzech ludzi nie przewyższa tej mocy ani jej nie ogranicza. Ograniczyć ja może tylko od strony człowieka brak dobrej woli, braj gotowości nawrócenia, czyli pokuty,

68 Por. K. R o m a n i u k, ,Jajestem zmartwychwstaniem” (J 11,25), „Concilium” 6-10: 1970, s. 228-234.

69 Por. R.E. B row n, dz. cyt., s. 9-12; G. A ng eli n i, Teologia morale fondamentale. Tradizioni, Scrittura e teoria, Milano 1999, s. 637-643.

70 RH, nr 9; Por. DM, nr 2; RM, nr 12.

71 TMA, nr 7.

72 Por. DM, nr 3; R. Tr e m b l a y, Approche pour fonder la morale chretienne sur le mystere de Jesus le Christ, „Studia Moralia” 19:1981, s. 213-249. 
trwanie w oporze i sprzeciwnie wobec łaski i prawdy, a zwłaszcza wobec świadectwa krzyża i zmartwychwstania Chrystusowego"73.

\section{TWÓRCZA NADZIEJA}

Nadzieja chrześcijańska nie jest pasywnym oczekiwaniem lepszej przyszłości, ale głoszeniem aktywności i świadomością, iż tylko przez krzyż można dotrzeć do światłości, która znaczona jest zmartwychwstaniem. Nadzieja chrześcijańska wymaga codziennej wierności posłuszeństwu Bogu oraz w służbie wobec bliźnich (por. Łk 10,30-37 ${ }^{74}$. Postawa posłuszeństwa wobec Boga powinna wynikać z wewnętrznego usposobienia człowieka. Wzorem jest tutaj Jezus (por. J 4,34; Flp 2,5-8), którego posłuszeństwo stało się powodem Jego wywyższenia i chwały (por. J 17,1); dlatego też dla chrześcijan posłuszeństwo stanowi ważny element weryfikacji ich przynależności do Boga w Jezusie Chrystusie (por. Mk 3,35) ${ }^{75}$. Taka postawa wymaga także otwarcia się na działanie Ducha Świętego ${ }^{76}$. Praktykowanie posłuszeństwa jest nie tylko upodobnieniem się do Jezusa, ale ma ono także wymiar apostolskiej nadziei ${ }^{77}$.

73 DM, nr 13.

74 Por. DC, nr 15; R. Tr e m b l a y, Radicati..., dz. cyt., s. 125-140; J. R a t z i n g e r, Wprowadzenie w chrześcijaństwo, Kraków 1970, s. 175-179; S. L e g a s s e, E chi e il mio prossimo? Studio sull'oggetto dell'agape nel Nuovo Tesatmento. Roma 1991, s. 9-33; R. Tr e m b l a y, La fiugura del buon samaritano, porta d'entrata nell'enciclica di Benedetto XVI „Deus Caritas est”, „Studia Moralia” 44:2006, s. 393-409.

75 Por. VS, nr 15; R. Tr e m b l a y, „Ma io vi dico”, dz. cyt., s. 132-142; J. R a tz i n g e r. Hasło „Rappresentanza/Sostituzione”, w: Dizionario teologico, t.3, Brescia 1969, s. 45-46; R. Tr e m b l a y, Radicati..., dz. cyt., s. 152-155; N . C a p i z z i, L'uso di Fil 2,6-11 nella cristologia contemporanea (1965-1993), Roma 1997, pass.; R. Tremblay. L'“innalzamento”, dz. cyt., s. 44-56; J . H e r i b a n, Retto fronein e kenosis. Studio seegetico su Fil 2,1-5.6-11, Roma 1983, pass.

76 Por. Ja n P aw eł II, Adhortacja apostolska „Vita consercata”, Citta del Vaticano 1996, nr 91-92.

77 Por. Jan P aw e 1 II, Adhortacja apostolska „, Redemptoris donum”, Citta del Vaticano 1984, nr 13. 
Chrześcijańska nadzieja winna być wiernością znaczoną ofiarą i hojnością zwłaszcza w nawróceniu serca. Przyznanie się do grzechu - rozpoczynające nadzieję nawrócenia - jest możliwe dzięki poznaniu siebie w świetle wiary pasachalnej i rozpoznaniu wartości człowieka w oczach Bożych ${ }^{78}$. Doświadczając grzechu i uświadamiając sobie zniewolenie, człowiek pragnie wyzwolenia. Jest ono możliwe przez wiarę w moc Misterium Paschalnego Chrystusa zostaje przywrócona utracona radośćc ${ }^{79}$.

To jest droga ugruntowująca nadzieję i wynosząca zbawczo krzyż do roli jedynej nadziei. Nadzieja ,jest to zatem cnota typowa dla homo viator, człowieka pielgrzyma, który zna wprawdzie Boga i wieczne powolanie przez wiarę, ale jeszcze nie dostąpił wizji uszczęśliwiającej”80. Na ziemi Duch Święty „chroni nas od złudzeń i od fałszywych dróg zbawienia, a kierując serce ku autentycznemu celowi życia, wyzwala nas z pesymizmu i z nihilizmu" 81 . Zatem cnota nie jest czymś abstrakcyjnym, oderwanym od życia, lecz przeciwnie, posiada głębokie «korzenie» w samym życiu, wypływa z niego i je kształtuje. Cnota wpływa na życie człowieka, na jego czyny i na jego postępowanie"82.

Prawdziwie wierzący jest zawsze twórczym odnowicielem świata, ponieważ działalność wynikająca $\mathrm{z}$ nadziei nie pozwala zatracić ostatecznego celu człowieka, ale jednocześnie z drugiej strony zaofiarowuje moce i siły ku codzienności ziemskiego pielgrzymowania. To są właśnie dary ku przemianie otaczającej i czasowej rzeczywistości, aby uczynić ją bardziej bliską i zgodną z Bożymi planami. Nic nie jest z tego wyłączone, winna bowiem obejmować całego człowieka

\footnotetext{
78 Por. RP, nr 13.

79 Por. RP, nr 31.

80 J a n P a w e ł II, Duch Święty zadatkiem eschatologicznej nadziei i sprawca wytrwania az do końca, w: Ja n P a we 1 II, Wierzę w Ducha Świętego, Pana i Ozywiciela, Citta del Vaticano 1992, nr 1.

81 Tamże, nr 4.

82 J a n P aw eł II, Przynieście radość i nadzieję. Przemówienie do młodzieży w Bazylice Watykańskiej, w: J a n P a w eł II, Nauczanie Papieskie, red. E. Weron, A. Jaroch, t. 1, Poznań 1987, s 89.
} 
w bogactwie jego samego jak i jego działalności ${ }^{83}$. Ostatecznie cała działalność ludzka ma na celu doskonalenie człowieka i świata, ku realizacji nadziei ${ }^{84}$.

W kategoriach wiary „nie chodzi tutaj o radość naiwną ani też o nadzieję próżna. Radość zwycięstwa nad złem nie przesłania realistycznej świadomości zła, które istnieje w świecie, i w każdym człowieku. Owszem, nawet tę swiadomość wyostarza (...). Dobro bowiem nie jest łatwe, jest ono zawsze tą «stromą ścieżką» (por. Mt 7,14). Tak więc radość z dobra i nadziei na jego zwycięstwo w człowieku i w świecie nie odsuwa na margines lęku o to dobro, o zniweczenie nadziei”85. Mimo wszystko „możemy więc mieć nadzieję na czwałę nieba, obiecaną przez Boga tym, którzy Go miłują i czynią Jego wolę. We wszelkich okolicznościach każdy powinien mięc nadzieję, że z łaską Boża «wytrwa do końca» i otrzyma radość nieba jako nagrodę wieczną Boga za dobre uczynki spełnione z pomocą łaski Chrystusa" ${ }^{\text {. }}$.

Rozwój jest także wezwaniem do współpracy z innymi, ale przede wszystkim z łaską Bożą. Dlatego Kościół patrzy na rozwój w świetle wiary, chcąc z jednej strony służyć Bożemu planowi, a z drugiej odpowiadać na wyzwania świata ${ }^{87}$. Miara rozwoju jest człowiek widziany całościowowo, a szczególnie ważne jest odczytywanie jego powołania wedle ,paramentru” wewnętrznego, który jest w naturze

${ }^{83}$ „W tej eschatologicznej perspektywie zadaniem wierzących będzie ponowne odkrycie teologalnej cnoty nadziei, o której «już przedtem usłyszeli dzieki głopszneiu prawdy - Ewangelii» (por. Kol 1,5). Fundamentalna postawa nadziei zjednej strony nie pozwala chrześcijaninowi stracić z oczu ostatecznego celu, który nadaje sens I wartość całej jego egzystencji, z drugiej zaś - dostarcza mu trwąłych I głębokich uzasadnień dla codziennego wysiłku przekształcania rzeczywistości zgodnie z Bożym zamysłem”. TMA, nr 46.

${ }^{84}$ Por. Jan Pawe 1 II, encyklika, Laborem exercens”, nr 9, 15; J a n P a w e 1 I I, Przemówienie wygłoszone na sesji plenarnej Międzynarodowej Organizacji Pracy, w: Dokumenty Nauki Społecznej Kościoła, t. 2, red. M. Radwan, i inni, Rzym-Lublin 1996, s. 219-233.

85 J a n P a w 1 II, Przekroczyć próg nadziei, Lublin 1995, s. 36-37.

86 KKK 1821.

87 Por. SRS, nr 31. 
właściwej człowiekowi stworzonemu przez Boga na Jego obraz i podobieństwo (por. Rdz 1,26). Wynika z tego, że prawdziwy rozwój polega ,nade wszystko na podporządkowani posiadania, panowania i użycia podobieństwu człowieka do Boga oraz jego powołaniu do nieśmiertelności"88.

\section{KULTURA ŚMIERCI}

Wobec bardzo zróżnicowanych przejawów kultury śmierci, która ujawnia się szczególnie wyraźnie współcześnie, orędzie wiary w Jezusa Chrystusa, w Jego śmierć i zmartwychwstanie jest szczególnym wyzwaniem dla człowieka wiary. Taki Jezus jest odpowiedzią wierzących na egoizm, niesprawiedliwość, nietolerancję czy negacje wobec godności człowieka. Rozeznając ,znaki czasu” można stosunkwo łatwo zauważyć, że ,stoimy wobec nadludzkiego, dramatycnzgeo zmagania między złem i dobrem, między śmiericą i życiem, między kulturą śmierci i kulturą życia" ${ }^{89}$. W tej materii działają wręcz „struktury grzechu" "90. W imię prawa do indywidualnej wolności usprawiedliwia się zamachy na życie i wręcz domaga się ich legali-

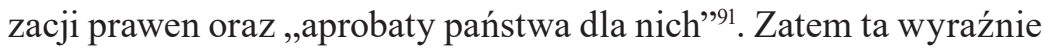
relatywistyczna wizja istoty człowieka i jego godności przyczynia się niejednokrotnie do promowania kultury śmierci, a więc brutalnego łamania praw człowieka, zwłaszcza prawa do życia ${ }^{92}$.

Jeśli zatem człowiek wierzy w Jezusa z Nazaretu zmarłego dla nas i że w jego śmierci jawi się nowe życie, zatem naszym powołaniem jest życie ku dawaniu życia dla naszych bliźnich. Tu ujawnia się najgłębszy sens egzystencji człowieka. Życie spotyka swe centrum, swój sens i swoją pełnię, kiedy jest dawane (por. J 15,13). Dowodem

\footnotetext{
${ }_{88}$ Tamże, nr 29; Por. E.M. C u r t i s, dz. cyt., s. 387-393.

89 EV, nr 28; Por. EV, nr 50.

90 Por. tamże, nr 12.

91 Tamże, nr 4.

92 Por. Jan Paw eł II, Nienaruszalne prawa istoty ludzkiej. Przemówienie do uczestników Miedzynarodowego Sympozjum nt. „«Evangelium vitae» a prawo”, „L'Osservatore Romano” 17:1996, nr 9, nr 4.
} 
najwyższej miłości jest ofiara z życia złożona za drugiego człowieka. Ten dowód miłości do bliźnich da Jezus na krzyżu, a uczniwie dadza go w życiu" ${ }^{93}$ „Musimy być mocni mocą miłości, która jest potężniejsza niż smierć" "94. Jednak ,człowiek nie potrafi o własnych siłach naśladowac i przezywać miłości Chrystusa. Staje się zdolny do takiej miłości jedynie moca udzielonego mu daru"95.

Można zatem powiedzieć, iż właściwą, czuwającą i otwartą postawą chrześcijańską w czasie winno być tu dziękczynienie i uwielbienie Pana. Ostatecznie każdy człowiek wiary jest powołany do dawania życia bliźnim, choć nie zawsze przybiera to formy pełnego radykalizmu miłości (por. Mt 5,1-12; 19,10-12.16-26) ${ }^{96}$. „Radykalizm decyzji o pójścia za Chrystusem wspaniale wyrażają Jego własne słowa: «kto chce zachować swoje życie, straci je; a kto straci swe życie z powodu Mnie i Ewangelii, zachowa je» (Mk 8,35)"997.

Jest to jednak możliwe tylko w Chrystusie, który dał przykład i moce Ducha Świętego (por. J 14,15-20; 15,26-16,15). Człowiek jest zdolny do rozpoznania prawdy o sobie, albowiem ,stworozny na obraz Boga (...) zostaje przez Ducha Świetego obdarowany sumieniem, ażeby obraz wiernie odzwierciedlał swój pierwowzór, który jest zarazem Mądrością i Prawem odwiecznym, źródłem ładu moralnego w człowieku i świecie"98. Duch Święty w łączności z dziełem

93 Por. R. Tr e m b l a y, Radicati..., dz. cyt., s. 125-140; Tenże, "Ma io vi dico", dz. cyt., s. 167-184; R. S c h n a c k e n bu r g, Il Vangelo di Giovanni, t. 3, Brescia 1989, s. 31-37: R. Tr e m b l a y, Voi, luce del mondo... La vita morale dei Cristiani: Dio fra gli uomini, Bologna 2003, s. 57-64; E.X. D u r r w e 11, Il Padre. Dio nel suo mistero, Roma 1998, s. 192-198.

94 J a n P a w e 1 II, Światło Roku Jubileuszowego na sakrament bierzmowania. Homilia podczas uroczystej Mszy św. ku czci świętego Stanisława, w: J a n P a w eł II, Nauczanie Papieskie, red. E. Weron, A. Jaroch, t. 2.1, Poznań 1990, s. 712.

95 VS, nr 22.

96 Por. S. L e g a s s e, La douceur d'apres le Noveau Testament, „La vie spirituelle" 1992, nr 702, s. 601-604.

97 VS, nr 66. Por. Tamże, nr 67-68.

98 J a n Paw e 1 II, encyklika ,Dominum et vivificantem”, Citta del Vaticano 1986, nr 36. 
zbawczym Chrystusa jest „Światłością sumień”99. W kontekście zaś ludzkiej słabości i grzechu Duch Święty dokonuje „oczyszczenia sumień"100.

To Jezus z Nazaretu oddał życie swoje za owce, aby miały je w obfitości (por. J 10,1-18). Zatem jest to wezwanie nie ku niszczeniu życia ale ku budowaniu szacunku dla niego, ku miłości i jego rozwojowi ${ }^{101}$. Śmierć niewinnych istot ludzkich nie ma dziś charakteru tylko przypadkowego, ale jest ,zaprogramowana w sposób naukowy i systematyczny”, przyjmuje formę „obiektywnego «spisku przeciwko życiu», w którym zamieszane są także instytucje międzynarodowe"102. Przyszłość jednak należy do kultury życia i miłości, a nie do kultury śmierci. Fundamentem tej andziei jest sam Chrystus, Pan Życia, który swoje wcielenie i zmartwychwstanie potwierdził nie tylko wartość życia ludkziego, ale tez jego ostateczne zwycięstwo. Dlatego potrzebna jest solidarne zaangażownaie ludzi dobrej woli w nowa ewangelziację na rzecz „cywilizacji życia”, broniącej jego świętości i nienaruszalności na każdym etapie istnienia, od poczęcia do naturalnej śmierci ${ }^{103}$.

99 Tamże, nr 42.

100 Por. Tamże, nr 44. „Ewangeliczne «przekoananie o grzechu» pod wpływem Ducha Prawdy nie może urzeczywistniać się w człowieku na innej drodze, jak tylko na drodze sumienia”, albowiem ,owocem prawego sumienia jest przede wszystkim nazywanie po imieniu dobraz i zła”. Tamże, nr 43.

101 „W tym miejscu nasze rozważanie staje sie uwielbieniem i dziękczynieniem, a zarazem skłania nas do naśladowania Jezusa i pójścia za Nim (por. 1 P 2,21). Także i my jesteśmy powołani, aby oddać życie za braci, urzeczywistniając w ten sposób prawdziwy sens i przeznaczenie naszej egzystencji. Jesteśmy do tego zdolni, bo Ty, o Panie, dałeś nam przykład I przekazałeś nam moc Twego Ducha. Zdołamy to uczynić, jeżeli każdego dnia, z Tobą i tak jak Ty, bedziemy posłusznie spełniać wolę Ojca. Dozwól zatem, byśmy umieli z sercem uległym I ofiarnym słuchać każdego słowa, które wychodzi z ust Bożych: w ten sposób nauczymy się nie tylko «nie zabijać» ludzkiego życia, ale będziemy też umieli je czcić, miłować I umacniać”. EV, nr 51.

102 Tamże, nr 17.

103 Por. Tamże, nr 100. 


\section{ZAKOŃCZENIE}

Chrystus, zmarły i zmartwychwstały zarazem, centrum kosmosu oraz historii jest faktycznym życiem i nadzieją ludzi i świata (por. Ap 22,13.20). Nie można Go już na zawsze oddzielić od tych wartości. On winien być opcją fundamentalną dzieła nowej ewangelizacji i wszelkich dzieł czynienia uczniów ze wszystkich narodów (por. Mt 28,19). Jezus Chrystus jest centrum wszelkich dzieł Kościoła - ludu Bożego Nowego Przymierza i każdego chrześcijanina. Dzięki tej obecności osobistej Chrystusa i asystencji Ducha Świętego, mimo największych przeszkód i trudności prowadizć będzie Kościół dzieło zbawienia ludzkości szczęśliwie do końca (por. Mt 18,8; 28,20). Chrześcijanie zaś winni być budowniczymi Jego dzieł oraz świadkami nadziei i życia.

Jezus Chrystus pozostaje jedyną nadzieją i drogą nowej ewangelizacji. Nie idzie tu jednak tylko o słowa czy nazwy, ale przede wszystkim realizm wiary oraz życia. Jego ciągle trwający czas bycia w eschatologicznych dziejach ludzi i świata jest wyjątkowym wyrazem obecności po spełnieniu paschalnego dzieła miłości. Jest ono najdoskonalszym darem ale i jednocześnie wyzwaniem ku zobowiązaniom życia i świadectwa.

\section{Summary Jesus Christ, Our Hope}

Questions about man, his freedom and liberation, are very important for human existence. Jesus Christ and His paschal mystery are the roots of Christian hope. Jesus is hope's bearer, however He requires our trust. Jesus Christ fulfills in Himself all the Messianic promises, especially the one of salvific newness of life in the New Covenant, also called the new humanity. The central sign of this newness is the coming of God's Kingdom. The universality of the Resurrection's gift brings us hope that all human beings might experience new life. The salvific gift refers to the renewal of the world in the renewal of all men. And yet, the voice of the culture of death - which is the negation of man, his dignity and his hope - is loudly heard in today's world. The culture of life, on the other hand, brings real hope, especially when it is marked by respect for life. The Christian attitude is one of thanking and 
praising the Lord in the power of the Holy Spirit. Christ is the hope of the people, of the world, and, therefore, of the new evangelization.

Słowa kluczowe: nadzieja, Jezus Chrystus, zmartwychwstanie, kultura życia, kultura śmierci, zaufanie

Key word: hope, Jesus Christ, resurrection, life's culture, death's culture, trust

\section{Bibliografia}

Angelini G., Teologia morale fondamentale. Tradizioni, Scrittura e teoria, Milano 1999.

B a lth a s a r H. U. v o n, Spiritus Creator. Saggi teologici, t. 3, Brescia 1972.

B a lt h a s a r H.U. vo n, Teodrammatica. 5: L'ultimo atto, Milano 1986.

B a l t h a s a H. U. v o n, Teologia misterium paschalnego, Kraków 200.

B e n e d y k t X V I, encyklika „Deus caritas est”. Citta del Vaticano 2005.

B row n R.E., Giovanni. Commento al Vangelo spirituale, Assisi 1999.

C a p i z z i N., L'uso di Fil 2,6-11 nella cristologia contemporanea (1965-1993), Roma 1997.

$\mathrm{C}$ u r t i s E. M., Image of God, w: The Anchor Bible Dictionary, t. 3, New York 1992.

D u r r w el1 E.X., Cristo nostra Pasqua, San Paolo 2003.

D u r r well E. X., Il Padre. Dio nel suo mistero, Roma 1998.

F it z m ye r J . A ., „Oggi sarai con me in paradiso” (Lc 23,43), w: Tenże, Luca teologo. Aspetti del suo insegnamento, Brescia 1991, s. 157-178.

F r o s i n i G., Lo Spirito che da la vita. Una sintesi di pneumatologia, Bologna 1997.

$\mathrm{F}$ u $\mathrm{m}$ a g a 11 i A., M a n z i F., Attierero tutti a me. Ermeneutica biblica ed etica cristiana, Bologna 2005.

G. v o n R a d, Genesi. La storia delle origini, Brescia 1993

Galot J., L'Esprit Saint, personne de communion, Saint-Maur 1997.

Gaspar V., Cristologia pneumatologica in alcuni autori postconciliari (1965-1995). Status quaestionis e prospettive, Roma 2000.

$\mathrm{H}$ e n g e 1 M., Il Figlio di Dio. L'origine della cristologia e la storia dekka religione giudeo-ellenistica, Brescia 1984.

H e r i b a n J., Retto fronein e kenosis. Studio seegetico su Fil 2,1-5.6-11, Roma 1983.

J a n P a w e $ł$ II, Adhortacja apostolska „Christifideles laici”, Citta del Vaticano 1988.

J a n P a we $\nmid$ II, Adhortacja apostolska „Pastores dabo vobis”, Citta del Vaticano 1992. 
J a n P a w e $\nmid$ II, Adhortacja apostolska ,Reconciliatio et paenitentia”, Citta del Vaticano 1984.

J a n P a w e $\nmid$ II, Adhortacja apostolska ,Redemptoris donum”, Citta del Vaticano 1984.

J a n P a w e $\nmid$ II, Adhortacja apostolska ,Vita consercata”, Citta del Vaticano 1996.

J a n P a w eł II, Bulla ogłaszajaca Wielki Jubileusz Roku 2000 „Incarnationis mysterium”, „L'Osservatore Romano” 20:1999 nr 1.

J a n P a w e $\nmid$ II, Dla chrześcijan sytuacja nigdy nie jest beznadziejna. Spotkanie w mtodzieża. Wsterplatte, „L'Osservatore Romano” 8:1987 nr 5bis.

J a n P a w 1 II, Duch Święty zadatkiem eschatologicznej nadziei i sprawca wytrwania az do końca, w: J a n P a w e 1 I I, Wierzęw Ducha Świętego, Pana i Ozywiciela, Citta del Vaticano 1992, nr 1.

J a n P a we $\nmid$ II, Encyklika „Dominum et vivificantem”, Citta del Vaticano 1986.

J a n P a we 1 II, Encyklika ,Evangelium vitae”, Citta del Vaticano 1995.

$\mathrm{J}$ a n P awe 1 II, Encyklika ,Laborem exercens".

J a n P a weł II, Encyklika ,Redemptoris missio”, Citta del Vaticano 1990.

J a n P awe 1 II, Encyklika ,Sollicitudo rei socialis".

J a n P a w eł II, Encyklika ,Veritatis splendor".

$\mathrm{J}$ a n P a we $\nmid$ II, Encyklika ,Dives in misericordia”.

J a n P a we $\nmid$ II, Encyklika ,Fides et ratio”, Citta del Vaticano 1998.

$\mathrm{J}$ a n P a we $\nmid$ II, Każdy człowiek nosi w sobie obraz i podobieństwo Boże. Przemówienie do uczestników Międzynarodowej Konferencji poświęcnej umysłowo chorym, „L'Osservatore Romano” 18:1997 nr 2.

J a n P a w e $\nmid$ II, List apostolski „Nuovo millennio ineunte”.

$\mathrm{J}$ a n P a w e 1 II, List apostolski, ,Tertio millennio adveniente”, Citta del Vaticano 1994.

J a n P a w e 1 II, Nienaruszalne prawa istoty ludzkiej. Przemówienie do uczestników Miedzynarodowego Sympozjum nt. „«Evangelium vitae» a prawo”, „L'Osservatore Romano” 17:1996.

J a n P a w e 1 II,Nowa ewangelizacja, postęp człowieka, kultura chrześcijańska. Przemówienie wygłoszone na otwarcie obrad IV Konferencji Ogólnej Episkopatu Ameryki Łacińskiej, „L'Osservatore Romano” 12:1992.

J a n P a we $\nmid$ II, Przekroczyć próg nadziei, Lublin 1995, s. 36-37.

$\mathrm{J}$ a n P a w e 1 II, Przemówienie wygłoszone na sesji plenarnej Międzynarodowej Organizacji Pracy, w: Dokumenty Nauki Społecznej Kościoła, t. 2, red. M. Radwan, i inni, Rzym-Lublin 1996. 
J a n P aw eł II, Przynieście radość i nadzieję. Przemówienie do młodzieży w Bazylice Watykańskiej, w: J a n P a e 1 II, Nauczanie Papieskie, red. E. Weron, A. Jaroch, t. 1, Poznań 1987.

J a n P awe 1 II, Światło Roku Jubileuszowego na sakrament bierzmowania. Homilia podczas uroczystej Mszy św. ku czci świętego Stanisława, w: J a n P a w e 1 II, Nauczanie Papieskie, red. E. Weron, A. Jaroch, t. 2.1, Poznań 1990. Jezus Chrystus, jedyny Zbawiciel świata, wczoraj, dziś i na wieki. Oficjalny dokument Papieskiego Komitetu Obchodów Wielkiego Jubileuszu Roku 2000, Katowice 1997.

Katechizm Kościoła Katolickiego.

Kongregacja Nauki Wiary, Deklaracja „Dominus Iesus”, Citta del Vaticano 2000. L a d a ri a L. F., Antropologia teologica. L'uomo: paradosso e mistero, Bologna 1997.

L e g a s s e S., E chi e il mio prossimo? Studio sull'oggetto dell'agape nel Nuovo Tesatmento. Roma 1991.

L e g a s s e S., L'Epitre de Paul aux Galates, Paris 2000.

L e g a s e S., La douceur d'apres le Noveau Testament, „La vie spirituelle” 1992, nr 702, s. 601-604.

M o 11 a t D., hasło „Chwała”, w: Słownik Teologii Bibilnej, red. X. Leon-Dufour, Poznań 1994.

Mszat rzymski dla diecezji polskich. Wydanie drugie, poszerzone. Poznań 2010.

P a w e 1 V I, Adhortacja apostolska „Evangelii nuntiandi”.

Penna R., L'apostolo Paolo. Studi di esegesi e teologia, Cinisello Balsamo 1991.

R a t z i n g e r J., hasło „Rappresentanza/Sostituzione”, w: Dizionario teologico, t.3, Brescia 1969.

R a t z inge r J ., Wprowadzenie w chrześcijaństwo, Kraków 1970.

Rey ni e r C., Tri ma i 11 e M., V a n h o y e A., Lettere di Paolo, t. 2, Cinisello Balsamo 2000.

R h o $\mathrm{n}$ h e i m e r M., La prospettiva della morale. Fondamenti dell'etica filosofica, Roma 1994.

R o m a n i u k K., ,Ja jestem zmartwychwstaniem” ( $J$ 11,25), „Concilium” 6-10: 1970, s. 228-234.

R u i z F., Le vie dello Spirito. Sintesi di teologia spirituale, Bologna 1999.

S c h n a c k e n b u r g R., Il Vangelo di Giovanni, t. 2, Brescia 1981.

S c h n a c k e n b u r g R., Il Vangelo di Giovanni, t. 3, Brescia 1989.

$\mathrm{S}$ e s b o u e B., Pedagogie du Christ. Elements de christologie fondamentale, Paris-Montreal 1977. 
Tre mblay R., „Ma io vi dico...”. L'agire eccelente, specifico della morale cristiana, Bologna 2005.

Tr e m bla y R., Approche pour fonder la morale chretienne sur le mystere de Jesus le Christ, „Studia Moralia” 19:1981, s. 213-249.

Tr e m b l a y R., L'“innalzamento" del Figlio, fulcro della vita morale, Roma 2001.

Tr e m b l a y R ., La fiugura del buon samaritano, porta d'entrata nell'enciclica di Benedetto XVI „Deus Caritas est”, „Studia Moralia” 44:2006, s. 393-409.

$\mathrm{Tr}$ e $\mathrm{m}$ b 1 a y R ., Radicati e fondati nel Figlio. Contributi per una morale di tipo fiale, Roma 1997.

Tr e m b l a y R., Voi, luce del mondo... La vita morale dei Cristiani: Dio fra gli uomini, Bologna 2003.

W e s t e r m a n n C., Genesi, Casale Monferrato 1989. 